\title{
Apresentação - A longa história do livro
}

\section{Presentation - The long history of the book}

https://doi.org/10.34112/2317-0972a2017V35n71p13-16

Alexandro Henrique Paixão

André Luiz Paulilo

O CONJUNTO DE REFLEXÕes QUE REUNIMOS AQUI SOB O TÍTUlo A longa história do livro trata o livro como protagonista de diferentes histórias entre os anos 1830 e 2010. A concentração de estudos acerca do século XIX, sobre a transição dos séculos XIX para o XX e a respeito da contemporaneidade do livro na era digital, reflete o interesse de muitas pesquisas pelo momento de afirmação do mercado editorial. No entanto, esses quase três séculos de história não são mais que uma ou duas frações do ciclo de vida de um artefato da cultura que tanto se consolidou como símbolo de status das classes educadas quanto circulou em meios populares desde a invenção da imprensa por Gutemberg no século XV.

Ainda que assim, o período é profícuo em temas e perspectivas de análises. A pesquisa sobre a história do livro atraiu pesquisadores de muitas áreas e matizes. Reconhecida por todos aqueles que hoje se dedicam à compreensão do livro e das práticas de leitura, as diferentes possibilidades de estudo, suas múltiplas preocupações, estão na ordem do dia ou melhor na "ordem dos livros". Mesmo na amostragem que se segue aqui, a variedade de abordagens testemunha o quão fértil é historiar o livro. Desde as mudanças das práticas de leitura e dos modos de catalogação dos livros até as trincheiras que o livro pode abrir no combate contra diferentes tipos de opressão. Muitas outras práticas somam-se a essas quando se toma o livro como fonte de pesquisa. Além da leitura, da escrita, da edição ou 
catalogação, têm-se em torno do livro a tradução, o comércio, o empréstimo, o aluguel, as anotações de margem e a digitalização. Há mais modos de lidar com os livros: a distribuição, a censura, o contrabando ou mesmo o roubo.

As perspectivas que o conjunto agora publicado privilegiou são as da história, da sociologia, da literatura e da educação, das suas interfaces e conexões. Da longa história dos livros recortaram-se, além de uma ou duas frações do seu ciclo de vida e de um conjunto de práticas, espaços da sua presença. A tela do computador, o banco de dados, as redações de revistas ou chefaturas de polícia, as livrarias, os gabinetes de leitura, as bibliotecas e as escrivaninhas de muitos públicos atestam a multiplicidade de lugares por onde os livros circularam ou ainda circulam. Do eixo Rio de Janeiro-São Paulo-Pernambuco a Paris e Lisboa, passando por Uruguai e Argentina, Estados Unidos e Inglaterra, emergem reflexões sobre as ligações que os livros entretecem entre imigrantes, tradutores, instituições e, enfim, leitores de diferentes países. De fato, por entre práticas e espaços de circulação, o livro envolve pessoas. Este dossiê também se ocupa delas.

Na longa história dos livros, homens, mulheres, crianças mudaram práticas, papéis sociais, espaços de circulação do escrito e o sentido e significado do ler e do escrever. Os "digital natives" de que fala Chartier, os tradutores observados por Norma Sandra de Almeida Ferreira, Maria das Dores Soares Maziero e Nelson Schapochnik, "os homens de letras" sobre os quais trabalharam Márcia Abreu e Adiel Mittmann, os presos políticos que emergem da análise de Mario Augusto da Silva Medeiros, os escravos alfabetizados apresentados por Atilio Bergamini, os caixeiros, professores e estudantes que das arcadas do colégio às vendas de secos e molhados habitavam espaços de leitura e saber atestam mudanças de muitos tipos, conforme atesta o último artigo dessa longa história, de autoria dos organizadores deste dossiê. Em três blocos de artigos sobre a presença do livro em diferentes momentos da história da cultura impressa, são dessas pessoas e das antigas e novas tecnologias que empregaram nas suas práticas do livro, por onde circulavam e de quais meios sociais provinham que este dossiê se ocupa.

O primeiro bloco, então, é formado por três artigos que recolocam a necessidade de compreender as antigas e novas tecnologias empregadas nas práticas do livro, leitor e leitura. O artigo de Roger Chartier, "Novas tecnologias e a história da cultura escrita. Obra, leitura, memória e apagamento", além de discutir as características das novas tecnologias no século XXI, as mutações na forma de ler e escrever e os sentidos da memória e do apagamento dos registros digitais "deletados", nos 
mostra como a revolução digital, ao mesmo tempo em que modificou os suportes da escrita, as técnicas de reprodução e disseminação, conservou até hoje certas maneiras de ler que vieram da Idade Média. Nessa direção, o artigo de Márcia Abreu e Adiel Mittmann nos apresenta o universo das "Humanidades Digitais", permitindo conhecer novas tecnologias, como o DLNotes2, que oferecem um suporte decisivo para a leitura de textos do passado, dando testemunho de que a "revolução digital" modificou profundamente os suportes da escrita e leitura, mas as formas de ler, a "leitura humana", para usar um termo dos autores, não foi substituída. Antes, segundo eles, as novas tecnologias tornaram mais "atenta e aguçada" a leitura e interpretação de textos conhecidos, sobretudo aqueles que foram alvo de crítica de câmaras censórias de séculos atrás, mas que sobreviveram até nossos dias. E por falar em livro censurado, com o artigo de Mario Augusto da Silva Medeiros "Livro de combate: o caso Em Câmera Lenta e sua repercussão pública no contexto da ditadura militar", somos apresentados para o terror contemporâneo da censura através do livro de Renato Tapajós. Esse artigo nos apresenta a intrincada tecnologia da censura no período da ditadura militar brasileira, mostrando como as formas de ler podem gerar processos de humanização ou de perseguição, tanto que um único leitor de Em Câmera Lenta, o Coronel Erasmo Dias, contrário a todo o público leitor da época, nacional e internacional, criou outro universo de sentido sobre o livro, aprisionando o autor num oceano de acusações infundadas e aparatos jurídicos, que testemunham que as tecnologias de censura e o medo do livro permanecem.

Como vemos até aqui, diferentes tecnologias condicionam a existência do livro e suas práticas. Já com o segundo bloco de textos, recuaremos um pouco no tempo e no espaço e encontraremos dois artigos dedicados a discutir como a "circulação transatlântica dos impressos" cria novas condições para o livro, o leitor e a leitura no Brasil e na América Latina a partir das traduções. O artigo de Norma Sandra de Almeida Ferreira e Maria das Dores Soares Maziero, intitulado "Que ninguém supporá que eu ignore o nome dos escriptos: João Köpke, o tradutor”, como o próprio título apresenta, discute o itinerário de tradução de João Köpke, convidando-nos a adentrar a trama de conhecidos autores de prosas ficcionais de língua inglesa e suas diferentes traduções para o vernáculo. Trata-se de um momento da história da cultura nacional e internacional que ajudou a realizar todo o comércio transatlântico do livro, com suas editoras, tradutores, consumidores, os mais diferentes "mediadores culturais", entre o final do século XIX e início do século XX. Ainda no contexto do comércio transatlântico de prosas ficcionais, o artigo de Nelson Schapochnik, "Dos Mistérios de Paris 
aos mistérios no Prata: tradução, imitação e invenção", apresenta-nos "as formas de circulação e os modos de edição sob os quais o romance de Eugêne Sue chegou [ou não] às mãos de leitores", sobretudo aqueles reunidos nas capitais banhadas pelo Rio da Prata. O artigo adentra o mundo dos catálogos de livros de bibliotecas latino-americanas e nos mostra como a "apropriação" de um livro se dá por diferentes vias, pois $O s$ Mistérios de Paris parecem ter inspirado muitos autores para além do território francês, mesmo quando não havia vestígios do romance no rodapé dos jornais argentinos e uruguaios, mistério de recepção que o artigo desvenda para nós.

O terceiro e último bloco de textos recoloca a tese de que as práticas do livro, do leitor e da leitura no século XIX brasileiro não são patrimônio das elites locais, antes foram engendradas por frações de estratos médios, baixos e também por populações escravizadas, localizados, principalmente, em duas regiões do país: Rio de Janeiro e Pernambuco. O artigo de Atilo Bergamini, "Escravos: escrita, leitura e liberdade", reúne um conjunto de anúncios da imprensa brasileira que testemunharam as práticas de leitura entre homens escravizados, demonstrando inclusive que "a leitura é mais disseminada que a escrita no século XIX brasileiro”, convidando o leitor a problematizar os sentidos da alfabetização, de leitura e escrita, e o papel dos impressos entre os setores populares. Por fim, o artigo de André Paulilo e Alexandro Henrique Paixão, "Das arcadas aos secos e molhados: a circulação do romance no Colégio Pedro II e no Gabinete Português de Leitura entre 1850 e 1880", busca combinar a circulação transatlântica do romance aos espaços de formação escolar (Colégio Pedro II) e não escolar (Gabinete Português de Leitura e seus ramos) no Rio de Janeiro oitocentista.

Observa-se que nesta longa história do livro, do século XXI ao século XIX, percorremos alguns momentos da história cultural em língua portuguesa, espanhola, inglesa e francesa, uma verdadeira "república [transatlântica] das letras". Adaptando a tese de Pascale Casanova à nossa, não tratamos aqui de uma história mundial das letras, ou melhor, do livro e suas práticas, ao contrário, a nossa longa história do livro carece de muitos complementos para abarcar os diferentes "momentos decisivos" dessa história da cultura entre os dois lados do Atlântico, da América Latina a Europa. Assim, sem dar conta dessa completude, os artigos reunidos aqui informam que aconteceu uma "revolução cultural" com o advento do livro, que foi alterando a si mesmo e às suas práticas na história, mesmo quando condições de manutenção e subsistência dos públicos leitores e os sistemas de decisão política dominantes apresentavam-se como extremamente precários e sem dar sinal de mudança. Essa dinâmica relação entre o texto e o contexto da sua produção é que os artigos aqui convidam a pensar. 